\title{
Entanglements of Faith: Discourses, Practices of Care and Homeless People in an Italian City of Saints.
}

\section{Introduction}

This paper critically investigates the ways in which Catholic-inspired services for homeless people are delivered in Turin, Italy. The work does not dismiss the value of what Faith Based Organisations (FBOs) do, nor does it criticise a-priori the stances of Catholic's love for the poor. FBOs, in Turin as elsewhere, provide fundamental services that are often the only available to homeless people and other populations. Nonetheless these services do have contextual effects that are not obvious at first sight. To investigate their practices, tracing the machinery through which such love becomes embedded into practices of care and engaging "with the religious framework that grounds them" (Hossler, 2012, p. 112) serves precisely the purpose of re-assessing the importance of the work of these organisations.

The literature on FBOs, which sits in the broader field of the geographical study of religion (Kong, 2001, 2010), provides the obvious starting point for such an endeavour (Beaumont, 2008a, 2008b; Conradson, 2008; Noordegraaf and Volz, 2004). Of particular relevance to this paper are the works of scholars like Cloke, Johnsen and May, which directly connect FBOs with urban homelessness $(2005,2007)$. Distancing themselves from the canonical approaches in the field, which have mainly been focused on the "revanchist" and "punitive" policies directed toward homeless people (see also DeVerteuil, May, and von Mahs, 2009), these authors have highlighted the presence of 
"new forms of collaborative ethical praxis, and new geographies of compassion and care, in the city" (Cloke, May, and Johnsen, 2010, p. 20). FBOs operating soup kitchens, shelters and other services, are seen in this sense as providers of liminal spaces that do not fit within the logic of "harassment" and control depicted by the established literature. Rather, these services paint a new compassionate scenario of care, which works as a (forgotten) counter-altar to more normative interventions, "opposing social and political urge to care for and serve homeless people" (Cloke, May and Johnsen, 2010, p.50).

The underlying motif of this renovated attention to FBOs' practices must be found in what Beaumont and Cloke, in a recent series of publications, call "postsecularism". The term is used in at least three, interrelated, forms: as a way of indicating that religions "are very much present and will not disappear irrespective of widespread aversion to the idea among certain liberal and secularist commentators" (Beaumont, 2010, p.6); as a theoretical tool to describe the abandonment, by secularism, of "certain rationalist assumptions over the disappearance of religion from the public sphere" (Romanillos, Beaumont, and Şen, 2013, p.42); and, more recently, as a term to indicate (and to normatively argue for) a "postsecular rapprochement", which identifies a "form of 'crossing-over' in the public arena between the religious and the secular" (Cloke and Beaumont, 2013, p.28). The city is, according to these authors, the space where the rapprochement between the secular and the religious (Cloke, 2010) takes place: in the use and design of public spaces, in the use of buildings, in models of governance, and in the engagement and composition of the civil society (Baker and Beaumont, 2011; Williams, 2013). FBOs then become pivotal urban actors of the rapprochement that characterises the postsecular scenario.

Despite the utmost importance of these contributions, which resides mainly in their ability to scatter a new light upon "the homeless city", critical points can be highlighted. If scholars have already questioned 
the relevance (Kong, 2010, p.765), and newness (Ley, 2011, p.xiii), of the notion of "postsecularism" (see also Wilford, 2013), this paper aims to contribute to the FBOs scholarship on homelessness addressing the most relevant shortcomings of the postsecular approach. The first is related to the lack of critical engagement with what FBOs do; while the second is concerned with bringing the urban machine back into the evaluation of these FBOs practices.

\section{A-critical love?}

One of the central tenets of the postsecular scholarship is that FBOs provide their services with (and through) love:

"[G]enerosity is constructed as far more love orientated than charitable, perhaps indicating some acquiescence to the secularisation of 'charity' and the recasting of generosity around the more exclusive Christian prompting of agape/love" (Cloke, Johnsen and May, 2005, p. 392).

"Agape" (love) and "caritas" are the two key-terms recurrently used to describe FBOs' approaches. If a particular terminology of fear and despair was central to the revanchist scholarship on homelessness (DeVerteuil, 2012), a different - but still "prophetic" (Wilford, 2013, p. 319) - tone underlies the postsecular scholarship. In the writings of Cloke and his colleagues we encounter "landscape of care" (Cloke and Beaumont, 2013; p.41); "Extraordinary Acts of Kindness" and "unconditional acceptance of the other" (Cloke, May and Johnsen, 2010, p.97-99); "gratuitous and creative giving of existence" (Cloke, 2010, p.233); "the unconditional outpouring of agape and caritas" (Cloke, May and Johnsen, 2010, p.115) - there is more in this vein (emphasis added). Christian "Iove", underpinning FBOs' actions in the postsecular city, is assumed as good and the few empirically-based case-studies provided by this train of thought unconditionally depicts it as such (e.g. Davelaar and Kersten, 2013). 
The issue, however, is not to determine if this love is good or bad - but rather to provide a critical and contextual assessment of it. The former term stands as an inclination to not take things (i.e. "love") for granted (Marcuse, 2009); while the latter invites us to appreciate that every urban space, like that of the "postsecular city", is a "perfomative social situation" where powerful dynamics are always at play (Thrift, 1996, p.43). The investigated literature does not adequately address these points. Firstly, when it confronts the work of scholars that have assessed that love fairly but critically (see Allahyari, 2000), it rapidly dismisses their contributions as "stereotypes" (Cloke, May and Johnsen, 2010, p. 250). Secondly, the only potential problem that postsecular scholars explicitly associate with (Christian's) FBOs practices is that of conversion, when they acknowledge the risk of "enforcement of the spiritual onto the other" (Cloke, May and Johnsen, 2010, p.54; on this point see also Cloke, 2010, p.233). However, as these authors acknowledge, this risk in contemporary FBOs is minimal. Thirdly, postsecular scholars mainly understand the city as a backdrop scenario where FBOs, along with more secular organisations, are involved in the "rapprochement" characterising postsecularism. The city, in other words, is seen from a macro or meso perspective - that of institutionalised actors that relate to each other constituting, in the end, a traceable history (Molendijk, 2010; for a distinction between macro and micro approaches to urban religion, see Stringer, 2013). However, this perspective does not allow a rendering of what Deleuze and Guattari call the "micropolitics of the social field" (1987, p.7): where is the "city" - with its more-than-human actants, contextual dynamics, power, affective atmospheres - in the "postsecular city"?

The paper argues that without critically and contextually addressing FBOs' "love for the poor", the literature dismisses, or at best skims over, the subtler effects of FBOs' practices. These effects can only be appreciated unfolding the daily interaction between the volunteers, the organisation, and the homeless subjects, and taking into consideration the "wider ecologies of intelligence" (Thrift, 2005a, p. 469) that populate any urban contexts. Cloke, May and Johnsen acknowledge the importance of these points in their attempt to remap the "homeless 
city" (2010, Chapter 3). Not only: when they do not frame their discussion under the postsecular umbrella, they provide vivid accounts of the nuanced dynamics taking place in soup run and day centres (see Johnsen, Cloke, May, 2005a;b), which better resonates with the findings of the broader literature on "spaces of care" (on the ambiguity of these spaces, see DeVerteuil and Wilton, 2009). However, when these and other scholars look specifically at FBOs using the postsecular approach, nuances and critical stances are largely replaced by an a-critical acceptance of the "love for the poor". Take for instance the following case, describing the instantiation of agape:

"The aim is to be non-interventionist, accepting of difference, and to bestow upon individuals the dignity to just 'be' without demanding anything in return. At a practical level, as one project manager explains, this may mean reminding volunteers that 'sometimes it's just about listening, it's not about having the answers'" (Cloke, May and Johnsen, 2010, p.99)

The problem with the a-critical acceptance of such assertion lies in its naiveté. Every kind of relation is interventionist by definition (it always changes the state-of-affairs of things; Latour, 2001); and something is always, even if unconsciously, demanded in return. The urban contexts where these practices of care take place are indeed produced through relations that sometimes are symmetrical, sometimes not, but they always demand an exchange: of materialities (bodies), emotions (fear, joy, etc.), moral discourses (of agape, but also of stigmatisations), points of view, assertions, passivities, etc. "Listening" is not - and cannot be - "just about". It is always, consciously and unconsciously, "something about": this is what the postsecular scholarship is not addressing critically enough.

\section{FBOs and the city: Discourses, practices and subjects}


In order to promote a "deeper theorisation of faiths and FBOs from an urban geographical perspective" (Beaumont, 2008, p.2021), one needs a contextualisation of love - which essentially means to critically evaluate it not from grand-narratives and macro-perspectives, but from the urban enmeshments within which it is produced, and for what it contributes to producing. There are two theoretical premises that have to be illustrated before presenting how such a contextualisation may be possible.

To begin with, love is never unconditional. Love is always a condition: it is the condition through which a particular form and a particular content of care are abstracted and turned into sets of territorialised assemblages that relationally affect subjective experiences of homelessness (Author's name, 2013). To put it differently, love is a form of (biopolitical) power (Anderson, 2012): it affects the subjects that relate under its diagrammatical spell (Deleuze, 1988; De Landa, 2000). Then, in order to grasp the minutiae of FBOs' "power-love", the city needs to be assessed (and methodologically accessed) from a micro and vitalist perspective. This means approaching it as a site of human and non-human relations of assemblages: a mechanosphere or a "machinic city" (Amin and Thrift, 2002) where all things are connected and affect each other in non-straightforward ways. In this sense FBOs, as well as homeless people, are not understood as divided from (or just located in) the urban (the macro-meso perspective), but rather part of it and constituted through it. They constitute precise urban contexts (such as shelters and soup kitchens) that, besides affecting urban aesthetic (Martin, 2010), contribute to the production of moral views (of the poor), materialized assemblages (like the distribution of clothes or food), and faith-driven spaces of care (Conradson, 2003). In a word, they produce - consciously and unconsciously - those diagrams of love that are not good or bad a-priori, but can only be understood contextually and relationally.

To picture the dynamics constituting FBOs' power-love, the paper proposes the notion of "entanglements of faith". ${ }^{1}$ This notion is an

\footnotetext{
${ }^{1}$ It is worth highlighting that I do not intend "entanglements" to be a pejorative term. The word stands only as an evocation of the intricateness of things, of their being interwoven in such a manner as to not be easily separated.
} 
invitation to identify and analyse those relations that are somehow affected by the discourses and practices specific to FBOs' interventions, and to evaluate them in terms of homeless people's responses. The entanglements can be identified paying attention to three (only analytically separated) elements: discourse, practice, and homeless subjects. Firstly, there are the discourses and the moral ethos expressed by the FBOs, such as the Catholic's "love for the poor". Secondly, there are the practices of care: here the discourses are interwoven with materialized assemblages that express their relational power through objects such as second-hand clothes, alms, free distribution of food, etc., which do not only constitute the FBOs' contexts, but travel the urban as well. Finally, there is the relational engagement of the homeless subjects with these assemblages, which take place in the form of conscious staging (Goffman, 1990), discursive refrains (Butler, 1993), and practiced space where composite urban agencies and atmospheres are at play (Anderson and Harrison, 2010; Gregson and Rose, 2000). In this work I pay particular attention to the emotional responses and affective atmospheres activated by these assemblages, taking into consideration the different ways homeless people relate to, and experience them (Desjarlais, 1997).

It is worth highlighting that discourse, practice and subject do not come in consequential terms. There is no prominence of one toward the other. On the contrary, they are understood to be parts of a continuos arrangement where "any point [...] can be connected to any other, and must be" (Deleuze and Guattari, 1987, p.7). Choosing the discursive side as the entry-point into the rhizome-entanglement, as the paper does, it is nothing more than a tactical manoeuvre aimed at increasing the clarity of the argument. From this side of the entanglement, the homeless subject is affected by the discourses enacted in the service: $s / h e$ is the recipient of the service. Words like "love", "care" and "caritas" - and others like "neighbour", "brother" and "poor", which are relevant in the particular context of Catholic FBOs - "do" things (Butler, 1993). In order to understand what they do, 
it is necessary to do more than enumerate different discourses: one needs to trace their moral genealogy, as well as underlining the complex mixture of intentions and ideas in circulation that, although not purely discursive, constitute the discursive formation of the FBOs' space (Foucault, 1990). At this point the second line of entanglement that of practice - becomes clearer. One of the things that these words and moral ethos do is to provide "blueprints for how food is served, for understanding the poor as guests or clients, and for organizational relations to the state" (Allahyari, 2000, p.13). Discourse and practice become entangled in the production of urban contexts of care where the experience of homelessness takes place. These are more-thanhuman spaces, where objects like a crucifix on a wall, or out-of-date food, have agencies that affect the human subject (Latour, 2004). The latter, understood as an assemblage that encompass the limit of the canonical self (Pile and Thrift, 1995), becomes through the relations with these more-than-human machineries (Guattari, 2010). It reacts to them; it stages responses; it turns them to its own advantage; it relates them to other urban machineries; or it passively accepts them. In any case, the subject is entangled within that space of assemblages, and it is affected by it. With this I do not aim to claim that FBOs produce homeless people's subjectivity. Rather, they contribute to the relational constitution of the experience of being homeless - as much as the other assemblages of the city do (Author's name, 2013, 2014).

The task of the critical assemblage-thinker is to follow these entanglements, tracing and unfolding them without over-imposing a pre-established narrative (such as that of the "postsecular rapprochement") on the course of action (McFarlane, 2011; Swanton, 2011). In what follows, after a contextual introduction to the fieldwork, the paper presents the entanglements of faith uncovered in Turin, unfolding the FBOs moral discourses around the "love for the poor", describing their enmeshment into practices of care, and tracing back their effects to the homeless subjects that experience them. 


\section{The case study: Cottolengo and Vincenziani in Turin}

Italian cities are far from being "postsecular". Rather, it could be argued, as has indeed been done by Italian scholars (Balbo, 2011), that Italy's civic ethos still lacks a mature secularism (Wilford, 2009). Although a recent study shows that religious marriages and baptisms are declining while, for instance, the use of contraceptives is increasing (CGIL, 2011), the extensive engagement of the Roman Catholic Church (RCC) in Italian national and local politics is still a tangible matter (Ginsborg, 2003). The urban contexts of Turin are no exception. Turin is commonly considered the city of the "Social Saints", because of the high number of Catholic figures who have established their activities and institutions in tackling poverty there - a tradition that started during the early modern era (Cavallo, 1995) and continues today (Governa and Author's name, 2010). If to this we add the fact that Italy does not provide a clear and well-defined national strategy on homelessness, the space that FBOs occupy assumes its full prominence.

The following parts of this paper rely on ten-months of ethnographic fieldwork conducted from September 2009 to June 2010 (Table 1). Despite the variety of materials collected, the paper focuses mainly on the longitudinal work conducted with Italian, male, long and short-term street dwellers (both interviews and observations), and on the experience of being a volunteer in the particular FBOs under investigation. The reasons why l've chosen to concentrate only on Italian men are threefold. Firstly, they are still the largest group of street dweller, and largest recipients of FBOs' services in the City. Secondly, both migrants (women or men) and Italian women have completely different relational patterns from those of Italian homeless men that would require an ad-hoc ethnography (Author's name, 2011). Lastly, a grounded analysis of FBOs' love entails an in-depth ethnographic investigation that necessarily requires practical choices to be made. In this sense, and despite its limitations, the material 
presented in the paper offers both a representative case of the entanglements of faith in Turin and a theoretical-methodological standpoint to inspire further investigations (see conclusions).

Table 1, Ethnography in Turin

\section{- Insert Table 1 about here -}

Source: The author

The paper focuses on two institutions that are a direct expression of the RCC, considered among the most important FBOs in Italy: the "Small house of the Divine Providence, Cottolengo" (a religious institution founded at the beginning of the $\mathrm{XIX}^{\circ}$ century near Turin by a priest, Don Cottolengo, who recently became a saint of the RCC with the name Saint Giuseppe Benedetto Cottolengo) and the Company of the Daughters of Charity of Saint Vincent de Paul (a Society of Apostolic Life for women within the RCC). More specifically, the paper focuses on two sub-components of these large institutions, namely the "Casa Accoglienza" (Welcoming House) and the "Casa Santa Lucia" (Saint Lucia's House), which manage the services for homeless people delivered by the Cottolengo and the Vincenziani. These institutions are the two biggest providers of first-aid services for homeless people in the City with an average, at the time of my fieldwork, of 450 hot lunches (Cottolengo) and 250 breakfasts and 150 packed dinners (Vincenziani) served every day, plus a whole range of other services to which I will turn shortly. No other institution in Turin provides anywhere near the same volume of services. Moreover, Catholics see these institutions as a reference to Christ's love for the poor as demonstrated, for instance, in the words used by former Pope Benedict XVI during his visit to Cottolengo in 2010: 
"This house is one of the ripe fruits born from the Cross and Resurrection of Christ, and manifests that suffering, evil, death does not have the last word". 2

\section{Entanglements of faith}

\section{Loving the poor}

The most relevant services provided by the Cottolengo's Casa Accoglienza, which is managed by a friar, are a counselling service, a soup kitchen (lunch), a dormitory, the free distribution of clothes, and the possibility of undertaking religious consultations. At the Vincenziani's "Casa Santa Lucia" the services are managed by a group of nuns, and include a morning soup kitchen, distribution of sandwiches (dinner), free distribution of clothes, free medical ambulatory, a counselling service and a monthly distribution of alimentary packages. I will now analyse the religious discourse and moral ethos upon which the activities of the two "Casa" rely. These discourses and moral ethos should be seen as animating the opera of these institutions, although not in strictly instrumental terms: they enmesh with particular practices, and inform them, rather than consequentially driving them (Allahyari, 2000).

Cottolengo's motto is: "Join us with an open heart, we will enter in your hearth". From the brochure describing the activities of the "Casa accoglienza" (Cottolengo, 2009) it is possible to discern the discourse on homelessness that power them. Cottolengo states that:

"The operative choices within which the Casa accoglienza operates are founded on a particular attitude defined as "loving concern for the poor" (attenzione premurosa verso il povero).

This concern is subsumed in the following principle: 
“'Caritas Christi urget nos' (The love of Christ leads us): founding the strength from God's love, the Casa accoglienza's service aims to respond to the Gospel's invitation of taking care of the poorest, in whom is recognized the presence of Jesus. Saint Cottolengo used to repeat that: "Poor are Jesus'".

It is worth noting firstly the reference to the Gospel. In the above passage Cottolengo's brochure is referring to the fact that the "love to the poor" is central to the Catholic faith and secondly, that Cottolengo states that the poor are not "like" Jesus but they are Jesus.

Vicenziani's motto is "Seeing Christ in the face of the poor". To understand this motto I refer to a book edited by the Vincenziani's community, given to me by one of the nuns of the "Casa" as a reference for their approach. Here is summarized the approach to the poor based on the teaching of Saint Vincenzo de Paoli, where it is possible to find the two "fundamental principles of the spirituality of the Vincenziani's communities". Those are: "The principle of the imitation of the Charity of Christ towards the poor" and "The principle of the faith in the presence of Christ in the poor". Concretely speaking, the Vincenziani should serve the poor "with love, utility" and for both "corporal and spiritual assistance" (Centro Liturgico Vincenziano, 2001, p. 18) always taking the individual into consideration as someone who "contains Christ". The same love and devotion attributed to Christ should hence be attributed to the poor, passing through material and spiritual assistance:

"Removing a material need, taking care of a physical or moral pain is a sufficient, although partial, object of the Christian and Vincenziani's charity. [...] The Vincenziani's charity will never forget the spiritual aspect of the need [...] and it will try, once given the material assistance, to see if from the friendship will rise a good atmosphere that allows even the spiritual help" (Ibid., 2001, p. 18). 
Therefore, material help leads to friendship, which in the end leads to spiritual help. But what is the goal of such spiritual help?

"From the colloquium on spiritual's problems it will emerge that the poor - who, like any other human being, is made for God wishes to serve God and part of his reign" (Ibid, p. 19)

The poor are thus seen as Christ but there is also the explicit exigency of "taking his soul to [...] God himself, of whom he needs like any other" (Ibid, p. 19). Homeless people are therefore seen as "poor", hence expression of Christ, but also as souls to be redeemed and helped in the name of God.

In the light of these discourses and moral stances it is possible to argue that if the power of "naming a thing is the power of objectifying, of totalizing" (Haraway, 1991, p. 79), Cottolengo and Vincenziani's argumentation that the poor are Christ leads to the objectification of the homeless by means of their characterisation: homeless people are characterised as a medium to reach God's love. A short detour will further illustrate this point.

At the base of Cottolengo and Vincenziani's discourses we can recognize the "Good Samaritan's love". The parable of the Good Samaritan, found in Luke's Gospel, is one of the most well-known and powerful tales telling how a Catholic is supposed to "love" other human beings. The most interesting part of this tale is the fact that Jesus tells us to love our neighbour. (In the parable a Samaritan - who represents the archetypical of the "stranger", the "foreigner" - offers his help to a dispossessed man that he finds in the street; see Luke 10:30-37 for the full parable). The central points in this tale are thus two. Love, which in Jesus' view implies not only an emotional attitude but also some concrete action ("he went to him and bandaged his wounds"; "he put the man on his own donkey"; "he took out two denarii and gave them to the innkeeper"). And neighbour, which is defined not by his characteristics, but only by two facts: he has been robbed (hence he is 
dispossessed) and a stranger (the Samaritan) has rescued him. The linkage between the two terms, love and neighbour, is a precise characteristic of God's commandments transmitted through the teachings of Jesus, and lies at the heart of catholic social interventionism (Brown and McKeown, 2000; Duncan, 2008). The former Pope, Benedict XVI, further clarified this in his first encyclical:

"Following the example given in the parable of the Good Samaritan, Christian charity is first of all the simple response to immediate needs and specific situations: feeding the hungry, clothing the naked, caring for and healing the sick, visiting those in prison, etc. The Church's charitable organizations [...] ought to do everything in their power to provide the resources and above all the personnel needed for this work" 3

Why should these organizations "do everything in their power" to love the poor? Jesus provides the answer: "Do this and you will live" (Luke, 10:28). The rationale and moral ethos behind the FBO's interventions on homelessness resides in the fact that homeless people are seen as vehicles through which eternal life (and therefore the eternal love of God) will be reached. The poor, in this sense, is loved; but this love, as any other power, is clearly not unconditional. The meaning and the collateral effects of this condition take on their full connotation when that "love" becomes entangled in the FBOs' practices.

\section{Practicing love}

The first set of practices taken into consideration here regards counselling services. In Vincenziani's case a lay volunteer conducted counselling without any specific qualifications: his approach was to listen to the homeless person and give alms or other goods as a form of first-aid help. More interesting was the case of Cottolengo's. Here

\footnotetext{
3 http://www.vatican.va/holy_father/benedict_xvi/encyclicals/documents/hf_ben-xvi_enc_20051225_deuscaritas-est_en.html (Retrieved in November 2011)
} 
the counselling, managed by a professional social worker, took place on two levels. First, a colloquium was necessary to obtain a renewable card that would have allowed the individual to access Cottolengo's basic services (such as the soup kitchen and the distribution of clothes). Marco, a young and short-term homeless individual, offers an account very common among the ones I met:

Me: What did they ask you?

Marco: Well, you know. Usual stuff.

Me: What?

Marco: Where I was coming from, how long have I been here... you know, these kinds of things.

Me: And what did you say to them?

Marco: That I want the card for the soup kitchen!

Me: And did they give that to you?

Marco: Not then. I've to go again, tomorrow. [...] Fuck them! I'm not going to tell them all my business. They can keep their card, I don't need that. I'm going to find food anyway.

(Marco, Dec. 2009, Semi-structured interview)

Second, the counselling also provided other services - like specific consultations and financial help - which required consecutive in-depth interviews. According to the social worker running the counselling:

"In 2009 I did 295 interviews. Among them, 5 individuals have decided to be helped by the Cottolengo and get on board with us".

Asked how a person might be helped in this way, she answered: "They start to be monitored by us when there is interest from both sides" (Feb. 2010, semi-structured interview). Homeless people often complained about the kind of questions that they needed to answer in order to gain access to these personalised services. As Carlo, a short-term homeless individual put it:

“I can't understand them. They know everything about me. They know that nothing has changed. You can tell this! But they continue to ask me the same things. And for what?" (Mar. 2010, Semi-structured interview). 
In order to participate in Cottolengo personalised services, individuals needed to demonstrate their willingness to follow a certain path, which would be expressed in numerous interviews and meetings with the social worker. However, this was unlikely to happen for the vast majority of people (as the number cited by Cottolengo's social worker clearly states). To fulfil the FBOs' counselling requirements the homeless person-in-case would have needed to be patient, meek and co-operative, not followed by any other institution, ready to trust these FBOs as able to help her/him, albeit not immediately. S/he should be, in other words, the "robbed man" ready to be helped by the Good Samaritan. The same dynamic also applied to the general colloquiums necessary to gain - or renew - the Cottolengo's service card. In the same way as Jesus, who does not tell us if the robbed man had anything to say in relation to the help that he was receiving, the colloquium were not designed to give voice to homeless people, but to offer the same standardised help to everyone (i.e. to every "neighbour").

However, both personalised and standardised help did not come unconditionally. As in the case of Marco and Carlo, anxiety, fear, but also boredom and frustration were the most common feelings among the homeless people I encountered. As many homeless people told me, counselling services are painful because the individual does not want to talk about their past without seeing the concrete opportunity of changing their situation. They are a source of stress, as they are asked the same questions every-time without getting anything - or very little - in return. Liebow pointed out the same whilst talking about homeless women:

"It is difficult to appreciate the intensity of feeling, the bonedeep resentment that many of the women felt at always having to answer questions, often very personal, and often the same ones, over and over again. But having to answer questions was part of the price they paid for being powerless" (Liebow, 1993, p. 137). 
The diagram-of-counselling affected the individuals in various ways: people learned how to lie, or run away, or simply waited with their head down until the colloquium was over. Everyone, however, was negatively affected by the atmosphere of these encounters (Anderson, 2009), and could do little to avoid them.

The second practice involves the distribution of food. From time to time in Vincenziani's soup kitchen volunteers not only distributed milk, tea, pizza and biscuits but also, according to what was available on the day, other goods. For instance I recorded the presence of Panettone (a typical northern Italian sweet eaten at Christmas) available from two weeks after Christmas until the end of February. The presence of so much Panettone "out-of-season" was due to the fact that the soup kitchen was receiving large amounts of food as donations. Some homeless people were accepting the Panettone anyway, mostly because no other choices were available. Others, however, were roughly refusing, arguing that they would not like "to eat Panettone at Easter" (Valerio, Jan. 2010, Field observation). A similar case concerned yogurt, which was served despite being out of date (the expiry date was usually just the day before). When the yogurt was available the vast majority of homeless people would first check the expiration date on the package then, if it had passed, either they would refuse it, or they would take it but complain about it. As I have showed elsewhere (Author's name, 2013), this was a practice common not only to Vincenziani but was also a widely diffused custom among other FBOs.

Another point relating to the distribution of food concerns the contextual atmosphere in which this practice took place. Both soup kitchens, although virtually open to anyone, were adorned with images of holy scenes sometimes accompanied by long biblical excerpts posted (or painted) alongside. In both cases a huge crucifix was standing directly in front of the main entrance, and at least in Vincenziani's case the morning breakfast always begun with a common 
prayer lead by one of the nuns. These arrangements annoyed homeless people, especially those of other-faiths. However, what annoyed them the most was the lack of personal space and a sense of being put "in the sty with all other pigs", as one of the soup kitchen was commonly described. Despite the frantic work of the volunteers, these spaces were largely overcrowded and terribly noisy, and homeless people had to fight to gain and preserve the necessary space in which to eat. Timing was strictly enforced. In Cottolengo's case, due to the large number of users, homeless people had to enter the soup kitchen in groups of 60 , having no more than 15 minutes each to eat. The fast turnaround, along with the smells, bodily contact, and lack of personal space, led to feelings of stress and tension. The pleasure of eating and its social dimension were, in other words, completely overturned by the affective and material atmosphere of these spaces. As Daniele, a longterm street dweller put it:

"I feel better in the bar, I rest there. I look at the people. They got TV too! ... Cottolengo is not for me. Too many people there. Too many immigrants. Have you ever been there? No, no, no. If I can, I eat Kebab here [...] if not, I better stay in the bar anyway!" (Daniele, Dec. 2009, Semi-structured interview).

Many homeless people, like Daniele, used the soup kitchen only as their last resort. For them the stress of being there was counteracted with the fatigue of finding alternative means to eat, like collecting alms in order to buy food in supermarkets or bars. This chain-of-effects, which extended beyond the boundary of the soup kitchen assembling with other urban contexts (like Daniele's bar), had its origin in FBOs' moral stances. The poor are the means through which God's love is accessed, and thus they need to be helped in any way: overcrowded rooms; out-of-date or out-of-season food; lack of privacy; quick turn over of meals; prayers; holy paintings; and no meaningful human contact; were all consciously and unconsciously seen as acceptable means of helping "the poor", because "the dispossessed" are (by 
definition) ready to accept anything. However, without underestimating issues arising from the lack of physical space and resources, the relevance of the situated effects of these services should not be dismissed.

The third and final case relates to the free distribution of clothes, and the Churches and FBOs' custom of giving spare coins to homeless individuals. Clothes-distribution was available in both institutions cited here almost in an unlimited fashion, allowing access to individuals as much as they wished. Conversely, the distribution of spare alms followed a less precise pattern - although there were Churches and FBOs where it was known on which day of the week the priest-in-charge usually distributed the money ${ }^{4}$.

Some homeless people knew every area of the city where free distribution of alms, clothes, shoes, food etc., would be taking place, and they developed the appropriate mental maps. Giorgio's account is, in this sense, illuminating. Giorgio, a long-term street dweller, usually spent his afternoon doing what he called the "tour". That was a journey that led him to three or four churches located in different areas of the city, which he reached by bus and tram. His purpose was to collect alms from the priests and nuns working in these churches. Giorgio was able to remember on what days this or that priest was giving alms. Moreover, he was able to arrange his "tour" in order to reach the right church on time while still having time to get to the others. Therefore Giorgio was using his cognitive ability to design a particular network in order to get what he needed, a network made up of buses, trams, priests, and behavioural patterns (since he was presenting himself to the priest as the "poor" who needed "charity").

Giuseppe's account, another long-term homeless individual, is equally interesting. In the days when the free distribution of clothes was

\footnotetext{
${ }^{4}$ Vincenziani's counselling service, of which I have said, followed a clear - although unwritten - schedule in the distribution of alms.
} 
available, he was collecting them from the Vincenziani and then was moving to Porta Palazzo (the City's biggest market). It was relatively easy for him to meet people there who were working in the black market taking place every Sunday around that area. Giuseppe was selling almost all the clothes that he had been given by the nuns receiving in return a little money, which in the end became one of his few means of income from life on the street. What is interesting to note is that Giuseppe de-territorialized the Vincenziani's service of first-aid clothes distribution into a new kind of assemblage, a work - or at least an income - opportunity (Author's name, 2013). Many homeless people did the same, showing a particular ability to entangle their own necessities to both the institutional and shadow machinery of the street (Venkatesh, 2008).

These new urban assemblages were created by the (almost) unlimited availability of spare alms or free clothes, resulting from the particular discourse on poverty spread by those FBOs - a standardised, unlimited material aid resonating with what the Samaritan says to the innkeeper: "when I return, I will reimburse you for any extra expense you may have" (Luke 10:35; emphasis added). These entanglements nonetheless affected the subjectivities of people, particularly long-term homeless individuals who, in the end, no longer felt the necessity of finding other ways of earning money: the alms and the black economy were good enough. As international literature has widely shown (e.g. in Italy, Bonadonna, 2005; in France, Dumont, 2007; and in the US, Snow and Anderson, 1993), homeless peoples' desires to return to a formal job were heavily undermined by the availability of such opportunities, which in the end were seen as an alternative means of sustaining life on the street. Moreover, the patterns designed by this geography of "unlimited help", were leading homeless people to frustration and emotional breakdown when such help was momentarily unavailable. Deprived of this help, they simply did not know what else to do (Author's name, 2011). The practice of distributing free clothes was not taking into consideration the lived worlds, and subjectivities, of these 
homeless people but only providing the same standardised response to everyone. A kind of help that only namely did not ask "anything" in return.

\section{Conclusions}

This paper fills a gap in the current postsecular literature, which thus far has failed to assess the non-evident effects of FBOs' "love for the poor". If, as one of the major source of inspiration for the postsecular scholarship puts it, "true belief is not only a doctrine, believed content, but a source of energy that the person who has a faith taps performatively and thus nurtures his or her entire life" (Habermas, 2006, p.8), the task of the critical postsecular thinker must be to contextually interrogate the moral basis and practiced ethos of that faith, which cannot be taken-for-granted (Marcuse, 2009).

The notion of "entanglements of faith" has been introduced to allow for such a contextual critique. What renders these entanglements different from more secularised interventions (Author's name, 2014) is the Catholic approach to "love for the poor". This is a "self-sacrificing love" with precise purposes, which can be questioned on the basis of its moral and discursive premise. The poor/neighbour is, indeed, Christ; $\mathrm{s} /$ he is a medium to reach God's love; s/he is portrayed as a materially deprived individual who needs (and will accept) any kind of material help. The practices of the investigated FBOs are coherent with these framings. Cottolengo and Vincenziani's services are of a "welfare universalist" form: the same for everyone, without any temporal limitation. However, as the paper has shown, the entanglements of these discourses and practices with the homeless subjects are by no means neutral. Emotional and physical responses are always, and often painfully, asked in return.

Despite its findings, the paper does not intend to undermine the work of the Cottolengo and the Vincenziani. The point, in fact, is not to 
eliminate the services but re-design them by accounting for their more nuanced dynamics. In this sense the paper has offered a theoretical, methodological and empirical basis upon which further investigations along these lines can be built. At least three fruitful areas could be explored. Firstly, FBOs produce assemblages that contribute to the constitution of the "homeless city". Soup kitchens, clothes distribution, shoes distribution, alms, distribution of alimentary packages and free medical assistance are all clear examples of assemblages that constitute particular urban contexts and travel beyond a singular institution. The latter aspect is, however, under-investigated. What kind of relational patterns do they enact (as in the case of the alms)? How do they populate the black market economy and its usage by homeless individuals? How do they reinforce precise paradigms of homelessness, through assemblages such as the out-of-date food (Gowan, 2010)? Secondly, if the welfarist approach of many FBOs does not pay enough attention to the heterogeneous subjects it encounters, the lack of resources and the increase in the numbers of the "poor" makes it difficult to operate these services differently. What kind of approach could eventually lead to an alternative way, one which is able to reconcile large-scale interventions with more attentiveness to unwanted consequences? How could it be possible to acknowledge the heterogeneity of the trauma of homelessness without typifying and simplifying it (Robinson, 2011)? Finally, FBOs (and more secular institutions as well) will need to construct new "habits of seeing and being that restore an oppositional value system" around homelessness (hooks, 1994, p. 170), in order to de-frame the canonical take currently re-enforced by their normative approaches (Amin, 2012). What philosophy of care, and what politics, could foster such a move?

To conclude, scholars and practitioners alike will need to work toward a different mobilisation of affect (Thrift, 2005b), one which is able to fully re-assess the emotional responses of FBOs' "recipients". Love, as with any discourse or practice, is a relational matter. The challenge is to recognise this, in order to move away from a unilateral perspective 
toward a more dialogical and mutual interaction; from the Samaritan, who expresses entanglements of faith "good" for everyone but also diagrammatical, to the acknowledgement of homeless people's peculiarities, nuances, and emotions.

\section{References}

Author's name. (2011). Homeless subjects and the chance of space. A more-than-human geography of homelessness in turin (unpublished Ph.D. thesis).

Author's name. (2013). Homeless people and the city of abstract machines. assemblage thinking and the performative approach to homelessness. Area, 45(3), pp. 358-364.

Author's name. (2014). Bringing the city back in. Critical assemblage thinking and the analysis of public policies on homelessness. City. (Forthcoming)

Allahyari, R. (2000). Visions of charity: volunteer workers and moral community. Berkeley: University of California Press.

Amin, A. (2012). Land of strangers. Cambridge: Polity press.

Amin, A., and Thrift, N. (2002). Cities, re-imaging the urban. Cambridge: Polity.

Anderson, B. (2009). Affective atmospheres. Emotion, Society and Space, 2(2), pp. 71-81.

Anderson, B. (2012). Affect and biopower: towards a politics of life. Transactions of the Institute of British Geographers, 37(1), pp. 28-43.

Anderson, B., and Harrison, P. (Eds.). (2010). Taking-place: non representational theories and geography. Farnham: Ashgate.

Baker, G., and Beaumont, J. (Eds.). (2011). Postsecular cities: space, theory and practice. London: Continuum.

Balbo, L. (2011). Questioni di sociologia (ma non solo). omissioni, silenzi, vuoti. Napoli: Scriptaweb.

Beaumont, J. (2008a). Introduction: dossier on faith-based organisations and human geography. Tijdschrift voor economische en sociale geografie, 99(4), pp. 377-381. 
Beaumont, J. (2008b). Introduction: faith-based organisations and urban social issues. Urban Studies, 45(10), pp. 2011-2017.

Beaumont, J. (2010). Transcending the particular in postsecular cities, in: A. Molendijk, J. Beaumont, \& C. Jedan (Eds.), Exploring the Postsecular, pp. 3-17. Leiden: Brill.

Bonadonna, F. (2005). In nome del barbone. vita di strada e povertà estreme in italia. Rome: Derive Approdi.

Brown, D. M., and McKeown, E. (2000). The poor belong to us: catholic charities and american welfare. New York: Harvard University Press.

Butler, J. (1993). Bodies that matter: on the discursive limits of "sex." Londom: Routledge.

Cavallo, S. (1995). Charity and power in early modern italy. Cambridge: Cambridge University Press.

Centro Liturgico Vincenziano. (2001). Il servizio dei poveri. nell'insegnamento di s. vincenzo de' paoli. Roma: Edizioni Vincenziane.

CGIL Nazionale. (2011). Vii rapporto sulla secolarizzazione. Retrieved from http://www.cgil.it/Archivio/NuoviDiritti/Secolarizzazione/Secolarizzazio n_2012.pdf

Cloke, P. (2010). Theo-ethics and radical faith-based praxis in the postsecular city, in: A. Molendijk, J. Beaumont, \& C. Jedan (Eds.), Exploring the Postsecular, pp. 223-241. Leiden: Brill.

Cloke, P., and Beaumont, J. (2013). Geographies of postsecular rapprochement in the city. Progress in Human Geography, 37(1), pp. 27-51.

Cloke, P., Johnsen, S., and May, J. (2005). Exploring ethos? discourses of "charity" in the provision of emergency services for homeless people. Environment and Planning A, 37(3), pp. 385-402.

Cloke, P., Johnsen, S., and May, J. (2007). Ethical citizenship? volunteers and the ethics of providing services for homeless people. Geoforum, 38(6), pp. 1089-1101.

Cloke, P., May, J., and Johnsen, S. (2010). Sweet up lives? re-envisioning the homeless city. Oxford: Blackwell Publishing.

Conradson, D. (2003). Spaces of care in the city: The place of a community drop-in centre. Social \& Cultural Geography, 4(4), pp. 507525.

Conradson, D. (2008). Expressions of charity and action towards justice: faith-based welfare provision in urban new zealand. Urban Studies, 45(10), pp. 2117-2141.

Cottolengo. (2009). Casa accoglienza. Carta dei servizi. Turin. 
Davelaar, M., and Kersten, W. (2013). A shelter from the storm: faithbased organisations and providing relief for the homeless, in: J. Beaumont \& P. Cloke (Eds.), Faith-based organisations and exclusion in European cities, pp. 199-218. Bristol: The Policy Press.

De Landa, M. (2000). Deleuze, diagrams, and the genesis of form. Amerikastudien / American Studies, 45(1), pp. 33-41.

Deleuze, G. (1988). Foucault. Minneapolis: University of Minnesota Press.

Deleuze, G., and Guattari, F. (1987). A thousand plateaus. New York: Continuum.

Desjarlais, R. (1997). Shelter blues: sanity and selfhood among the homeless. Philadelphia: University of Pennsylvania Press.

DeVerteuil, G. (2012). Does the punitive need the supportive? a sympathetic critique of current grammars of urban injustice. Antipode, DOI: http://doi.wiley.com/10.1111/anti.12001

DeVerteuil, G., May, J., and von Mahs, J. (2009). Complexity not collapse: recasting the geographies of homelessness in a "punitive" age. Progress in Human Geography, 33(5), pp. 646-666.

DeVerteuil, G., and Wilton, R. (2009). Spaces of abeyance, care and survival: The addiction treatment system as a site of "regulatory richness." Political Geography, 28(8), pp. 463-472.

Dumont, I. (2007). Tapecul, squat, soleil. vivre la détresse sociale dans le centre-ville. essai de géographie sociale. Caen: Presses universitaires de Caen.

Duncan, C. M. (2008). Catholicism, poverty and the pursuit of happiness. Journal of Poverty, 12(1), pp. 37-41.

Foucault, M. (1990). The history of sexuality, vol. 1: an introduction. New York: Vintage Books.

Ginsborg, P. (2003). Italy and its discontents: family, civil society, state: 1980 - 2001. London: Penguin.

Goffman, E. (1990). The presentation of the self in everyday life. London: Penguin.

Governa, F., and Lancione, M. (2010). La città del sociale: dalle immagini come retoriche alle "non-rappresentazioni" come pratiche, in: A. Vanolo and M. Santangelo (Eds.), Di Capitale Importanza. Roma: Carocci.

Gowan, T. (2010). Hobos, hustlers and back-sliders: homeless in san francisco. Minneapolis: University of Minnesota Press. 
Gregson, N., and Rose, G. (2000). Taking butler elsewhere: performativities, spatialities and subjectivities. Environment and Planning D: Society and Space, 18(4), pp. 433-452.

Guattari, F. (2010). The machinic unconscious: essays in schizoanalysis. London: Semiotext(e).

Habermas, J. (2006). Religion in the public sphere. European Journal of Philosophy, 14(1), pp. 1-25.

Haraway, D. J. (1991). Simian, cyborgs, and women. the reinvention of nature. London: Free Association Books.

hooks, b. (1994). Outlaw culture. New York: Routledge.

Hossler, P. (2012). Free health clinics, resistance and the entanglement of christianity and commodified health care delivery. Antipode, 44(1), pp. 98-121.

Johnsen, S., Cloke, P., and May, J. (2005a). Transitory spaces of care: serving homeless people on the street. Health \& Place, 11(4), pp. 32336.

Johnsen, S., Cloke, P., and May, J. (2005b). Day centres for homeless people: spaces of care or fear? Social \& Cultural Geography, 6(6), pp. 787-811.

Kong, L. (2001). Mapping "new" geographies of religion: politics and poetics in modernity. Progress in Human Geography, 25(2), pp. 211233.

Kong, L. (2010). Global shifts, theoretical shifts: changing geographies of religion. Progress in Human Geography, 34(6), pp. 755-776.

Latour, B. (2001). Gabriel tarde and the end of the social, in: P. Joyce (Ed.), The Social in Question. New Bearings in History and the Social Sciences. London: Routledge.

Latour, B. (2004). Nonhumans, in: S. Harrison, S. Pile, \& N. Thrift (Eds.), Patterned Ground. London: Reaktion books.

Ley, D. (2011). Preface: towards the postsecular city?, in: G. Baker \& J. Beaumont (Eds.), Postsecular cities: Space, Theory and Practice, pp. xii-xiv. London: Continuum.

Liebow, E. (1993). Tell them who am i. the lives of homeless women. New York: The Free Press.

Marcuse, P. (2009). From critical urban theory to the right to the city. City, 13(2-3), pp. 185-197.

Martin, D. (2010). Inscribing the general theory of secularization and its basic patterns in the architectural space/time of the city: from 
presecular to postsecular?, in: A. Molendijk, J. Beaumont, \& C. Jedan (Eds.), Exploring the Postsecular, pp. 183-206. Leiden: Brill.

McFarlane, C. (2011). On context. City, 15(3-4), pp. 375-388.

Molendijk, A. (2010). "God made the country, and man made the town": Some observations on the place of religion in the western (post)secular city, in: A. Molendijk, J. Beaumont, \& C. Jedan (Eds.), Exploring the Postsecular, pp. 147-162. Leiden: Brill.

Noordegraaf, H., and Volz, R. (Eds.). (2004). European churches confronting poverty: social action against social exclusion. Bochum: SWI Verlag.

Pile, S., and Thrift, N. (Eds.). (1995). Mapping the subject. geographies of cultural transformation. London: Routledge.

Robinson, C. (2011). Beside one's self. homelessness felt and lived. New York: Syracuse University Press.

Romanillos, J. L., Beaumont, J., and Şen, M. (2013). State-religion relations and welfare regimes in europe, in: Faith-based organisations and exclusion in European cities, pp. 37-58. Bristol: Policy Press.

Snow, D. A., and Anderson, L. (1993). Down to their luck. a study of homeless street people. Berkeley: University of California Press.

Stringer, M. D. (2013). Discourses on religious diversity. explorations in an urban ecology. Farnham: Ashgate.

Swanton, D. (2011). Assemblage and critical urban praxis: part two. City, 15(3-4), pp. 343-346.

Thrift, N. (1996). Spatial formation. London: Sage.

Thrift, N. (2005a). From born to made technology, biology and space. Transaction of the Institute of British Geographers, 30(4), pp. 463-476.

Thrift, N. (2005b). But malice aforethought: cities and the natural history of hatred. Transaction of the Institute of British Geographers, 30(2), pp. 133-150.

Venkatesh, S. A. (2008). Off the books. the underground economy of the urban poor. Cambridge, MA: Harvard University Press.

Wilford, J. (2009). Sacred archipelagos: geographies of secularization. Progress in Human Geography, 34(3), pp. 328-348.

Wilford, J. (2013). Book review: postsecular cities: space, theory and practice. Progress in Human Geography, 37(2), pp. 318-319.

Williams, A. (2013). Moralising the poor? faith-based organisations, the big society and contemporary workfare policy, in: J. Beaumont \& P. Cloke 
(Eds.), Faith-based organisations and exclusion in European cities, pp. 173-197. Bristol: The Policy Press. 